\title{
The first isolation of equine arteritis virus in Argentina
}

\author{
M.G. Echeverría ${ }^{(1,2)}$, M.R. Pecoraro ${ }^{(1,2)}$, C.M Galosi ${ }^{(1,3)}$, \\ M.E. Etcheverrigaray (1) \& E.0. Nosetto ${ }^{(1,2)}$ \\ (1) Cátedra de Virología, Facultad de Ciencias Veterinarias, Universidad Nacional de La Plata, calles 60 y 118 , \\ CC 296, 1900 La Plata, Argentina \\ (2) Consejo Nacional de Investigaciones Científicas y Técnicas (CONICET), Avenida Rivadavia 1917, C1033 AAJ \\ Buenos Aires, Argentina \\ (3) Comisión de Investigaciones Científicas de la Provincia de Buenos Aires, calles 10 y 526, 1900 La Plata, \\ Argentina
}

Submitted for publication: 8 August 2002

Accepted for publication: 24 September 2003

\section{Summary}

This paper describes the first isolation of equine arteritis virus (EAV) in Argentina. The virus was isolated from the semen of an imported seropositive stallion held in isolation at a breeding farm in Tandil in the Buenos Aires Province. In addition, viral nucleic acid was detected in seminal plasma using the reverse-transcription polymerase chain reaction. The isolated virus was propagated in cell cultures and confirmed as EAV by indirect immunofluorescence and virus neutralisation, using a serum specific for the reference Bucyrus strain of EAV. As far as the authors are aware, this is the first time that EAV has been isolated in South America. The equine industry is very important for Argentina and international movement of horses is very intensive. This finding may have effects on the international trade of horses and semen from Argentina.

\section{Keywords}

Argentina - Arterivirus - Equine arteritis virus - First isolation - Semen.

\section{Introduction}

Equine viral arteritis (EVA) is a disease which has been recognised in horses since the 19th Century. The causative agent, equine arteritis virus (EAV), was first isolated in Ohio, the United States of America (USA), in 1953 (3) and has been classified as an arterivirus of the order Nidovirales. Acutely infected animals may develop fever, leucopoenia, conjunctivitis, ocular discharge, and oedema of the scrotum, ventral trunk, and limbs. Severe clinical signs include respiratory distress with pneumonia or a pneumoenteric syndrome with colic, and abortion in pregnant mares $(1,8)$.

Equine viral arteritis can be transmitted via the respiratory or venereal routes. Aerosol exposure results in infection of pulmonary macrophages, with subsequent rapid spread via the circulatory system (6). Up to $60 \%$ of stallions acutely infected with EAV become chronically infected. Such 'carrier' stallions seroconvert, but shed virus constantly in the semen and this feature plays a significant role in the spreading of the disease within horse populations (14). Antibody to EAV can be detected in experimental infections four days post-inoculation by complement fixation, immunodiffusion and immunofluorescence (IF) tests (4, 9, 10). Neutralising antibodies develop two to four weeks following infection and levels can remain stable for several years (2). The virus neutralisation $(\mathrm{VN})$ test is the prescribed test for the detection of anti-EAV antibodies.

Surveillance and prevention measures currently being taken by the Servicio Nacional de Sanidad y Calidad Agroalimentaria (SENASA - National Agrifood Health and Quality Service) include sampling $0.05 \%$ of the equine population, annual certification for stallions and semen (both native or imported) as a prerequisite for inclusion on the service register, and paired sampling of all seropositive animals. In the case of imported horses, the animals are placed in isolation for fourteen days during which time blood samples are tested for antibodies against EAV. At present, vaccination against EAV is not 
permitted in Argentina, although the importation of vaccinated animals is allowed.

Routinely, imported stallions are tested by VN. Those with titres $\geq 1: 4$ without vaccination are tested further for persistent infection by virus isolation from semen or by test mating (6). This is the first isolation of EAV in Argentina, from the semen of such a seropositive imported stallion, detected by this routine monitoring.

Although antibodies to EAV were first detected in horses in Argentina in 1984 (11), to date no clinical signs of the disease have been reported and all previous virus isolation tests on horses with respiratory disease or aborted foetuses have been negative. Forty-six semen samples have been examined since 1996 in the laboratory of the authors, which is officially authorised to conduct EAV diagnostic tests.

\section{Materials and methods}

\section{Semen}

Two semen samples were collected $2 \mathrm{~h}$ apart from a seropositive stallion. The semen was processed immediately on arrival for assay using the reverse-transcription polymerase chain reaction (RT-PCR) as described below. For isolation, the seminal plasma was collected by centrifugation of the semen at $1,000 \mathrm{~g}$ at $4^{\circ} \mathrm{C}$ for $10 \mathrm{~min}$.

\section{Cell cultures and virus isolation}

Confluent monolayer cultures of rabbit kidney (RK-13) cells grown in six-well plates were inoculated with serial decimal dilutions ( $10^{-1}$ to $10^{-3}$ ) of seminal plasma in maintenance medium (MM), containing 2\% foetal bovine serum. A volume of $0.3 \mathrm{ml}$ of each dilution was inoculated in duplicate wells. Plates were incubated for $60 \mathrm{~min}$. at $37^{\circ} \mathrm{C}$ in an atmosphere of $5 \% \mathrm{CO}_{2}$ (13). After removing the inoculum, the cells were overlaid with MM. The cell cultures were reincubated at $37^{\circ} \mathrm{C}$ and examined daily for the appearance of viral cytopathic effects (CPE). Cultures which remained negative for CPE after six days were subjected to two additional passages before being considered negative. When viral CPE was observed, cultures were passaged onto RK-13 cells grown on coverslips, for subsequent examination by IF.

\section{Virus neutralisation test}

To confirm the isolate as EAV, complement-enhanced microneutralisation tests were performed (13). A stock of the isolates was produced in RK-13 cells, clarified, stored in aliquots at $-70^{\circ} \mathrm{C}$ and then titrated using the same cells. The reference sera anti-EAV Bucyrus (Dr Y. Fukunaga, Japan Racing Association, Tochigi, Japan), anti-equine herpes virus (EHV)-1 89C25 and anti-EHV-4 TH-20 (Dr T. Kumanomido, Japan
Racing Association, Tochigi, Japan) were heat-inactivated at $56^{\circ} \mathrm{C}$ for $30 \mathrm{~min}$. Serial two-fold dilutions were then prepared in serum-free medium starting at a 1:2 serum dilution. These dilutions were then mixed with an equal volume of $100 \times 50 \%$ tissue cell infective dose $\left(\mathrm{TCID}_{50}\right)$ of the isolates and $10 \%$ guinea-pig complement. After $60 \mathrm{~min}$. of incubation in an atmosphere of $5 \% \mathrm{CO}_{2}, 100 \mu \mathrm{l}$ of RK-13 cells $\left(3 \times 10^{5}\right.$ cells $\left./ \mathrm{ml}\right)$ were added.

\section{Immunofluorescence test}

Monolayer cultures of infected and non-infected cells, prepared in duplicate on coverslips, were washed twice with phosphatebuffered saline (PBS), dried and fixed with acetone at $-20^{\circ} \mathrm{C}$ for $30 \mathrm{~min}$. Anti-EAV Bucyrus antibody was reacted with the fixed cells as primary antiserum (1:16 in PBS) at $37^{\circ} \mathrm{C}$ for $45 \mathrm{~min}$. After washing three times with PBS, fluorescein isothiocyanatelabelled anti-equine immunoglobulin antibody (1:20 in PBS) was applied and incubated at $37^{\circ} \mathrm{C}$ for $45 \mathrm{~min}$. in a humidified atmosphere.

\section{Reverse-transcription polymerase chain reaction}

The RT-PCR assay had been previously established at the laboratory of the authors, using a modified method based on the procedure of Sekiguchi et al. (12). The Bucyrus reference strain of EAV (Dr H. McCollum, University of Kentucky, USA), propagated in RK-13 cells, was used to validate the assay and also acted as a positive control. Ribonucleic acid (RNA) was extracted from $250 \mu \mathrm{l}$ of Bucyrus EAV culture fluid and from $500 \mu \mathrm{l}$ of seminal plasma with $500 \mu \mathrm{l}$ of a mixture of guanidium isothiocyanate and phenol and precipitated with isopropanol. Complementary deoxyribonucleic acid (cDNA) was synthesised with $5 \mu$ of RNA resuspended in distilled water. A negative control was obtained by substituting sample RNA with the DNA of EHV-1. For the reverse transcription step, cDNA was obtained using reverse transcription and random hexamers. For polymerase chain reaction amplification, a pair of primers was chosen, designed to amplify a 449 base-pair (bp) region of the highly conserved matrix (M) gene (12). The oligonucleotide sequences of the primers and positions, based on National Center for Biotechnology Information RefSeq NC_002532, were as follows:

- M1 5'-CTGAGGTATGGGAGCCATAG-3’ -position 11894-11913- and

- M10 5'-GGCCTGCGGACGTGATCG-3' -position 12342 12325 .

The polymerase chain reaction was carried out in a final volume of $50 \mu \mathrm{l}$ containing $5 \mu \mathrm{l}$ of cDNA, $3 \mu \mathrm{l}$ of $\mathrm{MgCl}_{2}(25 \mathrm{mM}), 5 \mu \mathrm{l}$ of ten-times-concentrated PCR buffer, $1.25 \mathrm{U}$ of Taq DNA polymerase, $1 \mathrm{\mu l}$ of deoxynucleotide mix $(0.2 \mathrm{mM}$ each of deoxyadenosine 5'-triphosphate, deoxyguanosine 5'-triphosphate, deoxycytidine 5'-triphosphate, and deoxythymidine 5'- triphosphate) and $2 \mu$ of each primer 
(20 pM each). Denaturation, annealing and extension consisted of thirty-five cycles at $94^{\circ} \mathrm{C}$ for 45 seconds, $60^{\circ} \mathrm{C}$ for $1 \mathrm{~min}$. and $72^{\circ} \mathrm{C}$ for 90 seconds, respectively. The PCR products $(10 \mu \mathrm{l}$ samples) were examined on $2 \%$ agarose gels. The gels were examined under ultra violet light following ethidium bromide staining.

\section{Results}

The EAV was isolated from the semen sample in tissue culture. On day 5 of the second passage on RK-13 cells, a few rounded cells were observed in cultures inoculated with a $10^{-2}$ and $10^{-3}$ dilution of the seminal plasma. By day 2 of the third passage, the viral CPE was extensive in most cultures, consisting of cells becoming round, shrinking and detaching themselves. In the IF test, viral antigen was localised in the cytoplasm and especially in the perinuclear area, appearing as large masses occupying most of the cytoplasm. No viral CPE or virus-specific fluorescence was seen in mock-infected cells.

The isolated virus (designated La Plata 01) was confirmed as EAV by VN assay with an antiserum to the Bucyrus strain of EAV. The virus was not neutralised by either EHV-1 or EHV-4 antisera.

Using RNA extracted from cell cultures infected with the Bucyrus strain of EAV, cDNA was specifically amplified by RT-PCR. This single-round RT-PCR generated a product yielding a sharp, visible band of $449 \mathrm{bp}$ on an ethidium bromide gel. Identical bands were obtained from both the positive control and the semen sample, providing further proof of the identity of the virus as EAV. The negative control consisting of EHV-1 DNA produced no amplification band with the EAV-specific primer pair used in this study.

\section{Discussion and conclusions}

This is the first report of EAV isolation in Argentina. Serological evidence has been observed since 1984 (11). Serum samples used for those screenings were received in the laboratory of the authors for other purposes and their histories were unknown. However, EAV has not been implicated in cases of clinical respiratory disease, nor has the virus ever been recovered from abortion material or nasal swab samples. As in other countries, cases with clinical signs suggestive of EAV are not frequently reported $(5,11,15)$.

Since 1991, the VN test has been employed routinely in the laboratory of the authors to screen serum samples from imported and exported horses. To date, approximately 4,000 sera have been tested. Most samples were from thoroughbred and polo horses, and only on two occasions were positive sera detected. The first occasion was in 1993, when one imported stallion was found to be seropositive. The stud farm was temporarily closed and several serological studies were conducted on mares of the farm. The stallion was tested by test mating, but no seroconversion was detected among covered mares, nor was EAV isolated. On the second occasion, in 1998, several EAV-positive animals were detected on two stud farms that practised artificial insemination using imported semen. In view of these findings, the SENASA carried out an epidemiological survey to determine the prevalence of EVA in Argentina. Therefore, between August and October 1999, a comprehensive serological survey was carried out among registered stallions of quarter mile breeds, American trotters, heavy breeds and all riding, jumping and eventing breeds. The breeds selected for sampling were those with the highest records of importation of genetic material registered since 1995 (approximately 250 sera). In January 2001, another serological survey of 330 horses from stables within a $10 \mathrm{~km}$ radius of the establishment concerned was carried out. The two studies failed to identify any seropositive stallions.

Using a strategy combining RT-PCR and virus isolation, the authors were able to confidently detect virus in the semen of an imported carrier stallion and confirm the identity of the virus as EAV. The single-round RT-PCR used was sufficiently sensitive to detect EAV in the seminal plasma of this particular animal, and this strategy avoids the risk of false positive results through contamination, a problem inherent in the use of nested PCR assays.

The increase in international travel of horses for competition and breeding, and the use of semen for artificial insemination, have increased the risk of introducing EVA to countries previously free of the disease. Unless strict controls are implemented, there is a high risk of importing positive stallions or semen. Furthermore, active surveillance of horses within the country and investigation of suspect cases are also valuable ways of detecting incursions and allowing timely measures to be taken.

To control the spread of EVA by the venereal route, legislation forbidding EAV-persistently infected stallions has recently been introduced in Argentina. For this reason, the horse in question in this paper has now been castrated.

Further molecular characterisation of the EAV isolate is planned (7) to determine the phylogenetic relationship of the virus with other isolates worldwide. 


\title{
Premier isolement du virus de l'artérite virale équine en Argentine
}

\author{
M.G. Echeverría, M.R. Pecoraro, C.M Galosi, M.E. Etcheverrigaray \& \\ E.0. Nosetto
}

\section{Résumé}

Les auteurs relatent le premier isolement du virus de l'artérite équine (VAE) en Argentine. Le virus a été isolé à partir de la semence d'un étalon séropositif importé et mis en interdiction dans un élevage de Tandil (province de Buenos Aires). En outre, l'acide nucléique du virus a été détecté dans le plasma séminal par transcription inverse-amplification en chaîne par polymérase. Après isolement, le virus a été propagé par passage sur cultures cellulaires. Son identité a été confirmée par immunofluorescence indirecte et neutralisation virale au moyen d'un sérum spécifique à la souche de référence Bucyrus du VAE. Selon les auteurs, il s'agit du premier isolement du VAE en Amérique du Sud. L'élevage des chevaux revêt une importance primordiale pour l'Argentine, qui participe activement au transport international des équidés. Cette découverte risque d'avoir des répercussions sur le commerce international des chevaux et de la semence d'équidés en provenance d'Argentine.

\section{Mots-clés}

Argentine - Artérite virale équine - Artérivirus - Premier isolement - Semence.

\section{Primer aislamiento del virus de la arteritis equina en Argentina}

\author{
M.G. Echeverría, M.R. Pecoraro, C.M Galosi, M.E. Etcheverrigaray \& \\ E.O. Nosetto
}

\section{Resumen}

Los autores relatan el primer aislamiento del agente etiológico de la arteritis viral equina (AVE) en Argentina. El virus estaba presente en el esperma de un semental seropositivo importado que era mantenido en condiciones de aislamiento en una granja de reproducción de la ciudad de Tandil (provincia de Buenos Aires). Además, mediante la prueba de transcripción inversa asociada a la reacción en cadena de la polimerasa se detectó la presencia de ácido nucleico vírico en el plasma seminal. Tras replicar el virus aislado en cultivos celulares y aplicar técnicas de inmunofluorescencia indirecta y neutralización vírica para su identificación, utilizando un suero específico de la cepa Bucyrus (cepa de referencia para esa enfermedad), se confirmó que se trataba del agente de la AVE. De acuerdo con los datos obtenidos por los autores, esta es la primera vez que se aísla el virus de la AVE en Sudamérica. Debido a que el sector equino reviste gran importancia para Argentina $y$, dada la intensidad del movimiento internacional de caballos que se registra en el país, este descubrimiento puede repercutir en el comercio internacional de caballos y semen procedentes de Argentina.

\section{Palabras clave}

Argentina - Arteritis viral equina - Arterivirus - Primer aislamiento - Semen. 


\section{References}

1. Chirnside E.D. (1992). - Equine arteritis virus: an overview. Br. vet. J., 148, 181-97.

2. Crawford T.B. \& Henson J.B. (1973). - Immunofluorescent, light microscopic and immunologic studies of equine arteritis virus. In Proc. 3rd International Conference of equine infectious diseases (J.T. Bryans \& H. Gerber, eds), Paris, 1972. S. Karger, Basel, 282-302

3. Doll E.R., Bryans J.T., McCollum W.H. \& Crowe M.E.W. (1957). - Isolation of a filterable agent causing arteritis of horses and abortion in mares. Its differentiation from the equine abortion (influenza) virus. Cornell Vet., 47, 3-41.

4. Fukunaga Y. \& McCollum W.H. (1977). - Complementfixation reactions in equine viral arteritis. Am. J. vet. Res., 38, 2043-2046.

5. Gerber H., Steck F., Hofer B., Walther L. \& Friedli U. (1978). - Clinical and serological investigations on equine viral arteritis. In Proc. 4th International Conference of equine infectious diseases (J.T. Bryans \& H. Gerber, eds), Lyons, 1976. Veterinary Publications Inc., Princeton, New Jersey, 461-465.

6. Glaser A.L., Chirnside E.D., Horzinek M.C. \& de Vries A.A.F. (1997). - Equine arteritis virus. Theriogenology, 47, 12751295.

7. Hedges J.F., Balasuriya U.B.R., Timoney P.J., McCollum W.H., \& MacLachlan N.J. (1999). - Genetic divergence with emergence of novel phenotypic variants of equine arteritis virus during persistent infection of stallions. J. Virol., 73, 36723681

8. Jones T.C., Doll E.R. \& Bryans T. (1957). - The lesions of equine viral arteritis. Cornell Vet., 47, 52-68.
9. McCollum W.H. \& Bryans J.T. (1973). - Serological identification of infection by equine arteritis virus in horses of several countries. In Proc. 3rd. International Conference of equine infectious diseases (J.T. Bryans \& H. Gerber, eds), Paris, 1972. S. Karger, Basel, 256-263.

10. McGuire T.C., Crawford T.B. \& Henson J. (1974). Prevalence of antibodies to herpesvirus types 1 and 2, arteritis and infectious anemia viral antigens in equine serums. Am. J. vet. Res., 35, 181-185.

11. Nosetto E.O., Etcheverrigaray M.E., Oliva G.A., Gonzalez E.T. \& Samus S.A. (1984). - Arteritis viral equina: detección de anticuerpos en equinos de la República Argentina. Zentralbl. Veterinärmed., B, 31, 526-529.

12. Sekiguchi K., Sugita S., Fukunaga Y., Kondo T., Wada R., Kamada M. \& Yamaguchi S. (1995). - Detection of equine arteritis virus (EVA) by polymerase chain reaction (PCR) and differentiation of EVA strains by restriction enzyme analysis of PCR products. Arch. Virol., 140, 1483-1491.

13. Timoney P.J. (2000). - Equine arteritis virus. In Manual of Standards for diagnostic tests and vaccines, 4th Ed., OIE (World organisation for animal health), Paris, 582-594.

14. Timoney P.J., McCollum W.H., Roberts A.W. \& Murphy T.W. (1986). - Demonstration of the carrier state in naturally acquired equine arteritis virus infection in the stallion. Res. vet. Sci., 41, 279-280.

15. Timoney P.J. \& McCollum W.H. (1991). - Equine viral arteritis: current clinical and economic significance. Proc. Am. Assoc. Equine Pract., 36, 403-409. 